\title{
Gênero, sexualidade e docência: (re)pensando práticas
}

Gender, sexuality and teaching: rethinking practices

\author{
Cássia Cristina Furlan \\ Verônica Regina Müller \\ Universidade Estadual de Maringá
}

\section{Resumo}

A pesquisa objetivou analisar a opinião de professoras a respeito de gênero e sexualidade. Utilizamos a técnica de grupo focal, realizada em dois encontros com 13 professoras de uma escola municipal de Sarandi/ Paraná. Compôs instrumento de intervenção junto às professoras o jogo Trilhas da Diversidade juntamente com outros materiais de apoio. Os resultados mostraram que há entre as professoras receio ao lidar com as questões de gênero e sexualidade. Nesse sentido, é preciso criar situações de crise, oferecendo condições para que se produzam novas formas de entendimento e novas práticas de superação capazes de alargar horizontes. A escola tanto pode dar continuidade a preconceitos e estereótipos como favorecer a criação de espaços onde se discutam as diferenças e o respeito às diversidades.

Palavras-chave: Gênero. Sexualidade. Prática docente.

\section{Abstract}

The research aimed to analyze the opinion of teachers about gender and sexuality. We use the technique of focus group carried out in two meetings with 13 teachers of a public school in Sarandi / Paraná. The game Tracks of Diversity was the instrument of intervention with teachers along with other supporting materials. The results showed that among the teachers there is the fear to deal with issues of gender and sexuality. In this sense, it is necessary to install a crisis situation, offering conditions for the produce new ways of understanding and new practices for overcoming able to expand horizons. The school alike can continue the prejudices and stereotypes like to favor the creation of spaces where to discuss the differences and respect for diversity.

Keywords: Gender. Sexuality. Teaching practice.. 


\section{Introdução}

É crucial o entendimento de que, hoje, multiplicaram-se os modos de compreender, de dar sentido e de viver os gêneros e as sexualidades. Neste estudo, realizamos discussões a partir dos discursos de professoras $^{1}$ acerca da docência e da instituição escolar no tocante às questões de gênero e sexualidade. Foram realizados dois encontros com a técnica do grupo focal com as professoras (NETO; MOREIRA; SUCENA, 2002), visando a uma formação teórica que pudesse incentivar o trabalho pedagógico com essas temáticas na escola. Participaram da pesquisa 13 professoras de uma escola municipal da cidade de Sarandi/Paraná. Compôs instrumento de intervenção junto às professoras o jogo Trilhas da Diversidade ${ }^{2}$ juntamente com outros materiais de apoio.

Louro (2008, p. 20) aponta que "[...] novos saberes, novas técnicas, novos comportamentos, novas formas de relacionamento e novos estilos de vida foram postos em ação e tornaram evidente uma diversidade cultural que não parecia existir." Neste sentido, essas transformações, cada vez mais perturbadoras, passaram a intervir em setores que haviam sido, por muito tempo, 156 considerados imutáveis, trans-históricos e universais, como é o caso da instituição escolar.

A implantação de diversas políticas visando à incorporação de valores de respeito às diversidades, supõe a necessidade de se repensar o papel das escolas, no sentido de modificar a sua prática, para que possam ser realmente transformadoras na educação de meninos e meninas, e na sociedade em geral.

"[... tem professora que tem uma barreira [...]": formação docente, gênero e sexualidade

Em um primeiro contato com uma das professoras, perguntamos se havia algum tipo de abordagem quanto a essas questões na instituição escolar. Begônia $(2012)^{3}$ respondeu:

É abordado, mas aí fica muito... enquanto grade, enquanto conteúdo. Aí, quando surge é, algum questionamento, as professoras, elas, procuram trabalhar essa questão. Mas tem professora que tem uma barreira ainda muito grande, né... pra trabalhar, aí aborda 
muito superficialmente, ou então fala assim: "ah, não, ainda não tá na hora, vocês vão ver lá no quinto ano", entendeu... então, ainda tem muita barreira, elas tem uma dificuldade grande em se trabathar esse tema. (BEGÔNIA, 2012).

Após a resposta da professora, indagamos se ela considerava essa barreira como falta de formação a respeito dessas questões ou se observava outras razões.

Begônia: Ah... eu acho que é enquanto (...) é uma certa vergonha assim que elas tem, eu acho formação mesmo, e educação... tem essa dificuldade em falar sobre o assunto né. Não é nem assim principalmente uma falta de preparo, acredito que talvez não sabe como abordar esse assunto com essa faixa etária, né, por exemplo, quando um aluno de primeiro e segundo ano faz uma pergunta relacionada, de repente, não tem como, não sabe como falar, e as crianças hoje em dia estão muito precoces né, a gente observa, nossa, como eles estão assim, eles fazem perguntas assim, que a gente recorda que antes eles não tinham essa curiosidade, eles estão precoces, aguça a curiosidade né [...] (BEGÔNIA, 2012).

Muitas vezes, como afirma Cunha, Santos e Silva (2009), diante dos questionamentos e curiosidades das crianças a respeito dos órgãos sexuais e sobre a sexualidade, a reação de muitas/os professoras/es pode ser a de ignorar esses comportamentos, seja por falta de informação ou por não se sentirem à vontade com o tema. E esse comportamento pode levar muitas crianças a pensar na questão como algo que não deve ser tratado com adultos ou, muitas vezes, como um tópico nem mesmo permitido para discussões.

Não obstante a sexualidade vir sendo discutida na contemporaneidade, e tais discussões, inevitavelmente, atingirem as escolas (LẼ̃O; RIBEIRO, 2009), algumas ainda apresentam resistências em aceitar as problematizações sobre gênero, sexualidade, etnia, classe social como parte da educação global do indivíduo.

Ribeiro (2006) cita uma pesquisa realizada em Rio Grande/Rio Grande do Sul, com as professoras dos anos iniciais do Ensino Fundamental, evidenciando que elas utilizam distintos discursos e práticas para tratar da sexualidade nas suas salas de aula. 
Quando elas falavam desse tema, seja devido às perguntas formuladas pelas crianças, seja por estar estabelecido no programa escolar ( $4^{a}$ série), o discurso predominante era o biológico, em que eram explicadas as características anátomo-fisiológicas dos sistemas reprodutores masculino e feminino. Integrado a esse discurso atuaram outros, como o da família-reprodução em que a sexualidade se encontra fixada na reprodução, o que torna necessário o discurso biológico como mecanismo de controle da sexualidade e manutenção da família nuclear (branca, heterossexual, cristã). Em outras circunstâncias, quando as crianças manifestavam, em seus gestos, atitudes, brincadeiras, tipos de comportamentos associados pelos adultos (professores e pais) como vinculados à sexualidade, outras formas de interdição emergiam como as repreensões, as denominações pejorativas e as transferências de turma e mesmo de escola na tentativa de inscrever nos corpos dessas crianças, tomadas como anormais, as identidades de gênero e sexuais hegemônicas. (RIBEIRO, 2006, p. 104).

Observando essa análise realizada por Ribeiro (2006), notamos que, por vezes - e esses aspectos podem ser notados também na escola onde realizamos a pesquisa -, apareceram algumas referências a alunos e alunas que se desviavam da norma e, portanto, seguia-se uma tentativa de fazê-los/as aderir à normatização. Outros momentos faziam referências a certa regulamentação das experiências das crianças dentro das brincadeiras, com "medo" de que elas pudessem ter contatos vistos como próprios dos/as adultos/as, que não pertencem ao universo infantil, e, por isso, eram e são proibidos.

As professoras da nossa pesquisa demonstraram-se receosas com a possibilidade de trabalho dessas questões, principalmente quando aparecem situações referentes à homossexualidade, pois, para elas, é um assunto que poderia trazer diversos problemas, sobretudo com pai/mãe e familiares.

"[... nós teríamos um grande problema familiar [...]"

Nas discussões com as docentes, sobre o uso do Trilhas da Diversidade com as crianças, as professoras disseram:

Rosa (2012): nós teríamos um grande problema familiar ali também né, a questão da família. Algumas coisas que estão ali se chegasse ao ouvido dos nossos pais, eles viriam pra escola, chamaria atenção do diretor, do orientador, e até mesmo do professor, e ia até 
pro Pinga Fogo né (risos). Begônia: mas eu acho que envolve um trabalho com os pais. Begônia: de repente pros pais, [...] partindo da escola, dependendo a família, isso vai causar uma certa polêmica, digamos assim né.. mas, assim não que... porque na cabeça de alguns isso é um assunto proibido ainda né... (ROSA, 2012).

Há a presença/participação dos/as pais/mães e familiares na escola quando ocorre algo que, na concepção destes/as, poderia representar uma influência "negativa" para as crianças. As docentes usam como exemplo o fato de que muitos/as responsáveis pelas crianças poderiam até mesmo procurar a mídia, agindo como se esse tema fosse inteiramente proibido, principalmente na escola, local que exerce influência na constituição identitária das crianças.

Segundo Louro (2007),

[...] na implementação dessas disposições transgressivas ou, pelo menos, questionadoras, provavelmente iremos nos confrontar com muitas e variadas fontes de reação ou resistência, e talvez também encontremos aliados e parceiras. Para professoras e professores, especialmente de $1^{\circ}$ e $2^{\circ}$ graus, os familiares dos/as estudantes se constituem em participantes diretamente envolvidos nas práticas escolares, seja como companheiros seja como avaliadores das atividades, das propostas pedagógicas, da organização curricular, etc. Se os/as docentes detêm, institucionalmente, uma autoridade em relação às práticas educativas escolares, também os pais, as mães e demais adultos considerados "responsáveis" pelas crianças e adolescentes detêm autoridade sobre a sua educação, e, muitas vezes, essas concepções são divergentes e conflitantes. Não é possível, pois, esquecer que todas as iniciativas ou proposições que pretendam problematizar o consagrado e o convencional encontram, de imediato e em primeira mão, como interlocutora - parceira ou opositora, aliada ou inimiga - a família. (LOURO 2007, p. 125-126).

Entretanto, sendo a família parceira ou opositora, esses temas - conforme sugere as docentes - devem estar, frequentemente, presentes na vida das crianças. Seja na mídia, no dia a dia, ou por outras vias, elas "convivem com tudo isso" (HORTÊNSIA, 2012), e "só não vem da escola né" (AZALÉlA, 2012), "vem da rua, vem de casa." (BEGÔNIA, 2012). Nessa perspectiva, como propõe Soares (2006), diferenças étnicas, de gênero, 
sexualidades, regionalidades, são temas dos quais as docentes não costumam tratar, mesmo observando a presença constante deles no âmbito escolar e não- escolar. Begônia afirma que diversas situações se apresentam na vida das crianças, e precisariam ser problematizadas, "começando do marido bater na esposa, o pai bate na mãe, o vizinho... sofre violência sexual...", e a professora Hortênsia (2012) complementa: "dormirem todos no mesmo quarto, todo mundo no mesmo quarto. Crianças veem muita coisa ali, que, né, coisas do pai e da mãe", assuntos que possivelmente, se discutidos no ambiente escolar, poderiam, por exemplo, possibilitar que menos crianças fossem vítimas de violência sexual, um dos temas citados pela professora, ou então, menos crianças fossem vítimas de bullying por seu jeito de ser.

\section{"[...] você fala meio superficial, porque eu não vou abordar nada [...]"}

As professoras, por diversas vezes, citaram ações tomadas no cotidiano da escola, acreditando terem sido os momentos apropriados para lidar com as experiências transcorridas. Segue um exemplo dado pela Rosa:

Rosa (2012): então assim, na minha turma, essa semana nós tivemos um fato bem marcante, que uma menininha ficava apalpando o bumbum das outras, cinco apalpadas. Aí, eu perguntei pra ela assim: mas, porque que você está fazendo? Estou brincando. Mas porque que você está brincando? Aí a gente começou a conversar né. Aí eu perguntei pra ela assim: aí outra menina falou assim, ah professora, eu acho que ela é "pezão". Eu falei assim: você é "pezão"? Que que é "pezão"? "Pezão" professora, uma mulher que gosta da outra. Eu olhei pra cara dela e perguntei: você é "pezão"? Ela falou: não. (risos). Aí eu olhei pra cara dela e falei: Se você não é "pezão", se você gosta de... você gosta de mulher ou você gosta de homem? Eu gosto de homem... tá bom. Muito bem. Aí, a gente começou a conversar né... eu peguei e falei assim oh, a única coisa, você tem que respeitar. Ela não gostou, ela se sentiu ofendida de você ter apalpado o bumbum dela. Mas, se você vai escolher ser "pezão", igual as crianças comentaram, se você quiser namorar com uma outra moça, não tem problema nenhum. Aí a outra menina, ergueu a mãozinha, professora, minha tia é "pezão". Ela tem a namorada dela. Aí eu peguei e falei assim: olha gente, eu também tenho uma sobrinha que é "pezão", ela casou com uma outra mulher, mas nem por isso que eu vou desrespeitar a opção dela, mas só que naquele momento ali eu poderia estar conversando com ela, só que num outro momento eu não poderia 
estar fazendo isso, porque daí os pais cairiam em cima de mim. Sabe, eu acho que dependendo do local ali, como que está sendo abordado isso não, eu tiraria... esconderia... (ROSA, 2012).

Nesse exemplo, a professora tentou, a seu modo, problematizar a questão, inserindo as noções de respeito, segundo ela. Porém, ao aderir à nomenclatura sugerida pelas crianças e questionar a criança sobre sua sexualidade, implicitamente acaba direcionando a resposta da criança. Entretanto, percebemos que, quando surgem determinadas situações dentro de sala de aula, de uma maneira ou de outra, algumas docentes acabam problematizando os ocorridos. É preciso refletir principalmente sobre a maneira como realizamos a intervenção, pois essas situações podem causar grandes impactos na vida da criança, caso ela se sinta punida ou desprezada pelas demais crianças.

Outro exemplo dado pela professora dizia respeito a um projeto realizado nas escolas, com a utilização de jornais semanais para discussão de uma reportagem com as crianças. Uma reportagem continha a notícia do casamento gay.

[...] igual saiu àquela reportagem no Diário ano passado, o casamento gay. E, foi complicado abordar aquela questão com os alunos do quarto ano [...]. O dia que chegou o jornal, e tinha aquele rosto estampado, eu não trabalhei aquela semana. Eu [...] tirei aquela folha fora, porque, por causa que os pais ali, eles são, a maioria eles são evangélicos, eles não aceitam isso. [...] eu não abordei aquela reportagem, que tava na primeira capa (tom de descrédito)... eu fui num outro assunto que EU escolhi, que dominaria, do que aquele ali. (ROSA, 2012).

Margarida (2012) afirma que "você fica na saia justa né. Se você fala, se você defende isso, os alunos vão chegar em casa e vão falar pro pai... aí se você comenta, eles... você fala meio superficial, porque eu não vou abordar nada...". A professora Gloriosa (2012) expõe que "[...] é até questão de religião". E outra professora argumenta:

$A i$, eles querem saber, mas porque fizeram isso? Você vai tentar implantar ali a questão do direito... a questão do respeito, solidariedade, só que também você num, você também fica numa saia 
justa, dependendo a sua pregação ali em sala de aula... (ROSA, 2012).

Com essa discussão notamos que, implícita ou explicitamente, seja por falta de preparo, por preceitos religiosos, crenças e valores entranhados, muitas docentes sentem-se constrangidas sem saber de que maneira lidar com a circunstância. A falta de formação inicial e continuada é um aspecto que impede o tratamento da temática de forma mais aprofundada em favor do respeito às diversidades. $\bigcirc$ que a professora demonstra, em sua fala, indica a omissão de temas que deveriam fazer parte da educação escolar.

Não obstante, ocorrências, como a maior visibilidade dos sujeitos homossexuais e seu reconhecimento pela mídia, discussões sobre sexo e sexualidade, o aumento das relações afetivas e sexuais fora do casamento formal, entre outras, vêm rompendo antigas barreiras sociais, promovendo contatos com múltiplos sujeitos, saberes, modos de vida, valores e comportamentos que, necessariamente, afetam as instituições sociais, como tem ocorrido com a escola. Já não faz mais sentido negar a existência das mudanças de paradigma em processo.

Outra professora (Begônia), a respeito da experiência da professora Rosa, argumentou:

[... mas, não é a questão né, é algo que tá aí, que tá posto, é a lei que veio assim, digamos que, é... são amparados, têm os direitos, e aí, cabe depois a cada um, pensar da forma que quiser,eu acho que cada um tem uma opinião, mas é algo que está aí gente... está posto, tem que saber lidar... mas é isso mesmo, é uma preparação nossa, enquanto educadores... (BEGÔNIA, 2012).

A professora, a seu modo, defendeu a importância do trabalho dos educadores e educadoras, devido constituir-se o referente em questão de algo amparado por lei. Além disso, mesmo cada um tendo a sua opinião sobre o assunto, é função do educador e da educadora saber lidar com as situações, partindo do princípio do respeito, independentemente da convicção interna de cada indivíduo.

Autoras como Lionço e Diniz (2009) apontam que o medo ainda suscitado pela homossexualidade, resultante da formação cultural do Ocidente 
Judaico-cristão, impede maiores discussões sobre o assunto, reduzindo-as a estereótipos.

Essa estereotipia está na origem da omissão e descontentamento de algumas professoras ao se depararem com questões que vão contra essa fixidez assentada nas culturas, questões que ainda representam um incômodo para muitos e muitas que não aceitam ou não se permitem aceitar outras formas de expressão das identidades de gênero e sexuais.

Percebemos a quase unanimidade das opiniões das professoras em relação à necessidade de preparo, iá que sentem a falta dele para discutir as questões; elas enfatizaram a dificuldade com o trato dessas temáticas. Além disso, algumas professoras demonstraram não aceitar a homossexualidade, deixando implícito, em suas falas, que, por isso, recusam-se até mesmo a inserir na discussão. Entretanto, outras docentes mostraram-se abertas para aprendizagens que possam ajudá-las a melhorar sua prática docente, visando combater preconceitos e estereótipos.

Como supõe Furlani,

[...] a discussão de sexualidade na escola fascina muitos e apavora outros tantos; ou talvez melhor seria dizer que ela fascina e apavora, ao mesmo tempo, muitos. Mas vale registrar que o momento histórico que vivemos se mostra mais favorável a essa discussão: a política educacional oficial estimula e recomenda; a demanda infanto juvenil 'obriga'; pais e mães dividem-se entre a objeção, a indiferença e a manifestação favorável; professoras e professores a definem como projeto político pessoal e imergem na Educação Sexual. A sexualidade viva, no contexto cultural, é cada vez mais assunto obrigatório na Escola, em todos os seus níveis. Quer queiramos ou não, tudo indica que "o bicho vai pegar. (FURLANI 2005, p. 68).

Segundo a autora, talvez a ausência de informações acerca de certos aspectos da sexualidade não deva ser vista, simplesmente, como um não conhecimento, já que a ignorância pode se traduzir numa deliberada oposição ao saber. "Esse 'desejo de não saber' talvez aponte, por parte de quem o afirma, uma arrogante explicitação de 'já saber o necessário sobre' ou uma incapacidade, uma pretensa má vontade e relutância para admitir e reconhecer a existência do 'outro', daquele que é diferente, do marginal." (FURLANI, 2005, p. 87). 
Para Lionço e Diniz (2009), a função da educação não se reduz à transmissão formal de conhecimentos, devendo ser a escola um espaço onde se promova a cidadania.

"Eu sou bem tradicional mesmo, bem careta mesmo [...]": padronização e normatização de estereótipos e preconceitos

Mesmo sem perceber, nós, docentes, muitas vezes nos relacionamos distintamente, ou estimulamos determinados tipos de comportamento, conforme nossos/as estudantes sejam homens ou mulheres. Muitas vezes, esses fenômenos são sutis.

A professora Begônia (2012) aborda essa questão afirmando: "[...] mas até a gente às vezes acaba falando pras meninas: não brinca com menino, eles são brutos... eles não sabem brincar [...]. Com atitudes como a relatada pela professora, concorre-se para a normatização dos estereótipos. Perguntamos para as professoras quais estratégias pedagógicas ainda se apoiavam na diferenciação de gênero, por exemplo. Begônia (2012) afirma que é "[...] começando pela fila né. [...]". Para Gloriosa (2012), "é costume deles né". Hortênsia (2012), confirmando o apresentado pelas professoras relata fala dos/as alunos/as, dizendo "não, não vou na fila das meninas não. Às vezes até as meninas podem ir na fila dos meninos, mas eles não vão nas filas delas". E, Gloriosa (2012) continua: "[...] igual os banheiros né. Vai um menino errar e entrar no banheiro das meninas". Na sequência, Hortênsia (2012) relata o fato de que "[...] antigamente, não sei, mas parece que eu tenho uma lembrança, que os livros de chamada eram separados, primeiro os meninos depois as meninas. Já começava pelos livros né [...].

A partir do relato, notamos que as normas acabam sendo tão impostas e asseguradas que, até mesmo, as crianças acabam vigiando suas atitudes e suas ações para não correrem o risco de resvalar em características ou lugares considerados femininos ou, o contrário, masculinos.

De fato, os sujeitos são, ao mesmo tempo, homens ou mulheres, de determinada etnia, classe, sexualidade, nacionalidade; são participantes ou não de uma determinada confissão religiosa ou de um partido político... Essas múltiplas identidades não podem, no entanto, ser percebidas como se fossem "camadas" que se sobrepõem umas às outras, como se o sujeito fosse se fazendo "somando-as" ou agregando-as. Em vez disso, é preciso notar 
que elas se interferem mutuamente, se articulam; podem ser contraditórias; provocam, enfim, diferentes "posições". Essas distintas posições podem se mostrar conflitantes até mesmo para os próprios sujeitos, fazendo-os oscilar, deslizar entre elas - perceber-se de distintos modos. (LOURO, 2007, p. 51 ).

Esse é um aspecto a ser levado em consideração na educação, pois ainda há falta de reflexão quanto a certas atitudes tomadas por diversos/as professores/as, expondo o/a aluno/a em algumas ocasiões por apresentarem opções divergentes do esperado para cada gênero.

No entanto, além da falta de reflexão, também percebemos, na fala de algumas professoras, a recusa às situações de conflito e mudanças, tanto no âmbito dos gêneros quanto das sexualidades, como demonstra a fala da professora Rosa sobre a organização e disciplina impostas para a sua turma. Rosa (201 2): "[...] na fila ali, na organização ali, [...] eu sou bem tradicional mesmo, bem careta mesmo. Eu fui educada igual minha mamãe. Meninos prá cá, e meninas pra lá [...]."

Após esse relato, a professora Hortênsia (2012) complementa: "[...] é tudo tradicional. Porque antigamente, pras meninas parar de conversar, como é que nós sentávamos? Lembra das carteiras, sentava uma menina e um menino, pra não conversar. Que daí as meninas não conversavam com os meninos." Em seguida, a professora Rosa (2012) emenda: "[...] ah, sou tradicional mesmo viu Hortênsia [...] e olha lá, o povo é tudo na linha."

Nesse sentido, refletimos sobre as discussões relativas à escola na modernidade, pois esta foi organizada espacial e temporalmente de acordo com certas regras presentes nas instituições que, segundo Foucault (2000), formaram a sociedade disciplinar, sendo então uma das instituições de grande utilidade na normatização, no disciplinamento do sujeito moderno, tendo caráter disciplinador. E, segundo a fala da professora Rosa, alguns aspectos da escola moderna ainda parecem estar presentes no dia a dia da prática docente. $\bigcirc$ corpo infantil, no enclausuramento escolar, parece estar, muitas vezes, preso no interior de poderes muito apertados, que the impõe limitações, proibições e obrigações. "A disciplina fabrica corpos submissos e exercitados, corpos 'dóceis'." (FOUCAULT, 2000, p. 164). 
Como supõe Foucault (2000), há um princípio, dentro dos quadros disciplinares, chamado "[...] princípio da localização imediata ou do quadriculamento $[\ldots]$ ", aspecto observado no ambiente escolar:

Cada indivíduo no seu lugar; e em cada lugar, um indivíduo. [...] Importa estabelecer as presenças e as ausências, saber onde e como encontrar os indivíduos, instaurar as comunicações úteis, interromper as outras, poder a cada instante vigiar o comportamento de cada um, apreciá-lo, sancioná-lo, medir as qualidades ou os méritos. Procedimento, portanto, para conhecer, dominar e utilizar. A disciplina organiza um espaço analítico. (FOUCAULT, 2000, p. 1691.

Na prática docente relatada por Rosa, percebemos esse princípio do quadriculamento, impondo certa disciplina às crianças, para que algumas práticas não fujam do controle e da vigilância constantes, fortalecendo a manutenção do controle sobre os corpos, circunscrevendo-os na matriz heterossexual a fim de que reafirmem suas identidades ditas "normais" para cada gênero. Quanto à sexualidade, percebemos implícito o discurso do adiamento para mais tarde, para depois da escola, para a vida adulta.

Sendo assim, cada passo em falso pode levar a punições e demarcações que vão reafirmando os valores e as concepções das crianças, segundo determinada normatização cultural, construindo percepções estereotipadas e, muitas vezes, equivocadas de certos assuntos, por não serem estes problematizados na escola. Pelo contrário, às vezes, esses temas são até mesmo negados pelas docentes, reafirmando proibições e impossibilitando, dentro da educação escolar, uma percepção mais crítica por parte da criança. Nesse contexto, determinadas informações poderão ser entranhadas da forma como professores e professoras "tradicionais" estão "pintando", ou então ressignificados por outras representações implicadas fora do ambiente escolar.

Por isso, questionamos as professoras sobre a sua prática docente, visto que pode exercer grande influência na manutenção de preconceitos e estereótipos presentes na sociedade. Notamos, em algumas delas, a insistente permanência de valores e pensamentos que impossibilitam uma docência capaz de levar as crianças à reflexão crítica sobre alguns assuntos. Rosa (2012) diz: "[...] não quero mudar [...] e ó, eu, eu... eu te garanto, que eu 
posso catar o meu povo de Deus e sair em qualquer lugar, eles não fazem feio $[\ldots] . "$

A escola, neste sentido, acaba por produzir diferenças, distinções e desigualdades. Na escola, seja pela afirmação ou pelo silenciamento, é exercida uma pedagogia da sexualidade, legitimando determinadas identidades e práticas sexuais, reprimindo e marginalizando outras. Instâncias sociais, como a mídia, a lgreja e a família, também praticam tal pedagogia, seja coincidindo na legitimação de sujeitos, seja produzindo discursos distantes e contraditórios. (LOURO, 2007).

Nessas práticas rotineiras e comuns, precisamos redobrar nossas atenções recorrendo aos mecanismos de questionamento, ou, ao menos, abrindo espaço para a desconfiança. Para a autora, a tarefa mais urgente talvez seja exatamente essa: "[...] desconfiar do que é tomado como 'natural' [...]" (LOURO, 2007, p.63), interrogando essa padronização e normatização de preconceitos e estereótipos que impedem a constituição de diferentes identidades.

Essa pedagogia da sexualidade de que Louro fala é também utilizada pelos/as próprios/as alunos/as, visando à regulação das identidades contraditórias e fora do nexo da "normalidade". A professora Hortênsia dá o exemplo de um aluno, sobre essa questão:

[...] aqui na escola também tinha um rapaz que ele chega: Hortênsia estão me chamando de viadinho la professora bate na perna em exagero afeminado e voz) (risos). Aí esses dias, eu encontrei com ele tudo de batom, cabelo e salto, isso e aquilo [...]. (HORTÊNCIA, 2012).

Com esse exemplo, a professora demonstra como as crianças, no ambiente escolar, já têm fixada uma certa identidade a ser seguida, e qualquer identidade que fuja dessa fixidez identitária é tachada com apelidos, como: 'pezão', 'viadinho', 'bichona', 'sapatona', e tantos outros termos pejorativos usados para discriminar o/a diferente. Além disso, há um sentimento de pena e de vergonha. Outro exemplo dado pela professora Gloriosa também aponta para essa direção:

[...] tem um menino, o pai dele é super machista. E ele, esses dias ele falou assim pra mim: 'Gloriosa, to fazendo crochê'. Aí eu falei: 
'ai deixa eu ver Mateus, teu crochê'. Ele jogou um tapete lindo assim no meu colo, e fez assim: 'ai, não é lindo'. 'É Mateus'. 'Ai, eu quero fazer balé, meu pai não quer deixar eu fazer balé'. Eu falei assim: 'ah, deixa o menino fazer balé papai'. $\bigcirc$ pai dele falou assim: 'ah Mateus, isso não é coisa de homem. O Mateus me fode, esse moleque'. Aí ele: 'não é lindo, deixa eu fazer balé, deixa, deixa pai'. Eu falei: 'põe o menino no balé'. Aí o pai dele olhou assim: 'Ih, isso não vai prestar'. Eu falei: 'ah, caramba'. (GLORIOSA, 2012).

A visão fundada na matriz heterossexual sequer admite a possibilidade de um homem fazer crochê e balé sem comprometer sua masculinidade, e menos ainda aceita formas de expressão da sexualidade que transcendam o binarismo. Impõem-se demarcações limítrofes aos papéis masculinos e femininos, e a escola continua omissa seja por ainda reproduzir o pensamento da matriz heterossexual, seja por não estar preparada para enfrentar a situação, seja por medo do conflito, entre outras razões.

Entretanto, a negação dos/as homossexuais no espaço legitimado da sala de aula acaba por confiná-los às gozações e insultos, fazendo com que jovens gays e lésbicas só possam se reconhecer como desviantes, indesejados ou ridículos. Mesmo quando, aparentemente, o que está em jogo são as escolhas por determinadas práticas que possam não dizer respeito à sexualidade, legitima-se a garantia da "norma". Neste sentido, a ignorância e a arrogância mantêm os valores e comportamentos adequados para cada gênero. Há um estranhamento, explicitado pelas professoras, percebido, sobretudo, no não-dito, na expressão corporal das mesmas, que caracteriza uma negação aos/ às homossexuais. No caso do primeiro exemplo, o encontro posterior com o aluno que assumiu uma identidade transgênero causou desconforto para a professora, visto que o/a aluno/a fugiu à norma social, assumindo uma identidade desviante.

Aqueles e aquelas que conseguem suportar e se impor diante das diversas tecnologias de governo dos gêneros e das sexualidades, enfrentam situações de sofrimentos e constrangimentos inimagináveis. Se, hoje, percebemos que as classificações dos gêneros e das sexualidades não dão mais conta das possibilidades de práticas e de identidades, não significa, entretanto, que os sujeitos transitem livremente entre os territórios ou que sejam igualmente considerados. Alguns setores sociais passam a demonstrar crescente aceitação da pluralidade sexual, mas, por outro lado, setores tradicionais renovam seus 
ataques que recorrem até mesmo a manifestações extremas de agressão e violência física.

"[... ele não tem orientação na casa, tem pai de chocadeira [...]": educação sexual ${ }^{4}$ na escola

Nas diversas falas das professoras, percebemos recorrentemente a presença de discursos indicativos da manifestação da sexualidade no dia a dia das crianças. Begônia (2012) afirma que "os meninos assim, tem meninas que são bem danadinhas, tem meninos que é uma de passa a mão nas meninas, na fila não dá muito certo, porque daí eles vão encostando, é complicado", referindo-se a certa configuração da fila ainda separada por gênero. E Hortênsia (2012) complementa: "é um tal de passar, conforme o comprimento da sainhas, passa a mão na bunda (sinal)".

Após essas falas, as professoras se referiram à importância da conscientização com as crianças, visto que percebem a presença já marcante de manifestações da sexualidade. A Begônia (2012) diz: "tem que ter uma conscientização, tem que se trabalhar muito, pra ir se adaptando". E Gloriosa (2012) continua: "porque às vezes a gente coloca o prézinho na fila, todo mundo junto, junta... 'o, você é homem, vai lá...' sabe...". Nesses relatos, notamos o quanto já estão presentes e, muitas vezes, internalizados, certos estereótipos que se perpetuam antes mesmo de a educação escolarizada inserir certa diferenciação de gêneros, quando alunos e alunas fiscalizam-se para que não se transponham as fronteiras de gênero. Entretanto, ao genderizarem-se $e^{5}$ espaços, ações e situações cotidianas, as possibilidades de interação entre as crianças diminuem, mas, sendo o ambiente o mesmo, os contatos passam a acontecer com frequência e a comunidade escolar não sabe como lidar com as experiências e atitudes das crianças. Um exemplo disso é a fala da professora Rosa, dando relato sobre sua experiência como mãe:

[...] minha filha fica no recanto [...] $\bigcirc$ moleque catou ela, e jogou ela no chão, ele, diz ele, diz ela, que ele gosta dela. Ele pegou ela e jogou no chão, e falou pra ela assim: 'eu vou transar com você'. (risos). A Iza ficou desesperada. Ela ficou desesperada gente. A minha filha, 10 anos, a Iza, assim, ela tem um conhecimento assim, das coisas, da questão do transar, do sexo, como uma coisa bonita. Não como aquela coisa agressiva igual esse abençoado. Ela pegou veio conversando comigo, na época eu ainda estava 
casada, ela perguntou: mamãe, você e o papai transam? Eu falei: não, nós não transamos, nós fazemos amor. E ai, eu fui mostrando. Daí ela pegou e me contou. No outro dia, (risos gerais), fui lá na escola no outro dia. Eu fui lá e conversei com a orientadora, e falei pra orientadora assim ó: 'põe esse moleque longe da minha filha, porque se esse infeliz chegar perto da minha filha novamente, a minha filha não é nem um animal, nenhuma cadela pra ficar jogada no chão, pra servir de cio pra qualquer cachorro não'. A orientadora (sinal de assustada)... porque a minha filha, ela vai ser educada assim, ela vai respeitar os outros, ela vai ter o momento dela, ela vai conhecer o amor da vida dela, e ela vai construir, ela vai ver essa parte sexual ai, essa relação entre um homem e uma mulher como uma forma bonita. Não como uma forma agressiva. [...] Mas olha, eu fiquei revoltada pela maneira, a violência que ele pegou ela. [...] ele não tem orientação na casa, tem pai de chocadeira (agressivamente). Não, as coisas assim, eles não tem limites. (ROSA, 2012).

Como afirma Braga (2009), no espaço escolar há uma aparente dessexualização, todavia esta não consegue se perpetuar, pois os fatos ocorrem, querendo ou não. Louro (2007, p. 80) chama a atenção para a comum e 170 equivocada forma como educadores/as encaram a discussão sobre a sexualidade. Eles pensam que "[...] se deixarem de tratar desses 'problemas' a sexualidade ficará fora da escola." As consequências da ausência de informações sobre a sexualidade podem ser claramente sentidas em nossa sociedade, em que a liberdade de expressão é exercida de forma fragmentada e deturpada, como apresentado pela professora Rosa, na atitude do menino sobre sua filha, sem necessariamente compreender a dimensão do ocorrido. $\bigcirc$ tema precisa ser tratado de forma sistemática, consciente e responsável pela e na escola.

Furlani (2007), ao falar em educação sexual, se refere a uma educação em qualquer nível de ensino, caracterizada pela continuidade.

Uma continuidade baseada em princípios claros de um processo permanente - porque o bombardeamento midiático de informações recebidas por crianças e jovens é permanente... porque as situações de exclusão social, decorrentes do sexismo e da homofobia, são constantes... porque as representações hegemônicas que hierarquizam as diferenças estão permanentemente sendo fixadas mesmo com permanentes resistências... porque a subjetivação da 
sexualidade (que talvez tenha um papel maior do que, até então, temos considerado nessa dinâmica de mudança comportamental) está sendo permanentemente posta em questão pelos aparatos discursivos de uma cultura e precisa ter o contraponto reflexivo de uma educação sexual sistemática, corajosa, honesta e politicamente interessada com a crítica desses modelos de desigualdade sexual, de gênero, de etnia, [...] de geração, de classe, de religião, etc. (FURLANI, 2007, p. 68).

Para a autora, o principal papel da educação sexual é desestabilizar as "verdades únicas" e apresentar as várias possibilidades sexuais presentes no social, na cultura e na política da vida humana, problematizando o modo como são significadas e como produzem seus efeitos sobre a existência das pessoas. Esse processo necessário precisa ser contínuo e é importante para a quebra de paradigmas no campo do gênero e da sexualidade.

\section{Quebra de paradigmas: o que fazer enquanto educador/a}

Dispostas/os a implodir a ideia de um binarismo rígido nas relações de gênero e sexualidade, teremos de ser capazes de um olhar mais aberto, de uma problematização mais ampla, que terá de lidar com múltiplas e complicadas combinações de gênero, sexualidade, classe, etnia, as quais estão presentes em todos os arranjos escolares (LOURO, 2007).

Nada, nem as aparências, os gestos, os modos de se vestir podem identificar ou caracterizar alguém, pois são atributos culturais construídos ao longo da vida. Esse assunto esteve presente na seguinte fala da professora Azaléia (2012): "[...] porque a gente às vezes fala assim, que a delicadeza faz a pessoa ser gay né, e aí você vai ver tem um monte de segurança de boate, um baita de uns policiais aí e são... não é ah... quer mais, do que o policial ser um [...]."

Podemos supor que na escola onde realizamos a pesquisa há carência de trabalhos com as docentes e com as crianças sobre as questões de gênero e sexualidade. Em diversos momentos, notamos, sobretudo, por parte das professoras, resignação em relação às estruturas patriarcais, sexistas e homofóbicas presentes na sociedade. Contudo, situações escolares nas quais seja possivel observar um questionamento dessa esquemática polarização talvez sejam muito mais frequentes do que a priori se supõe. 
Assim, concordamos com Lessa (1999) quando propõe o estatuto da dúvida, do questionamento, da constante interrogação como uma forma de pensar uma nova educação, que suporte a mudança e apresente desafios, enfim, que instigue o aprendizado, respeitando as crianças em suas múltiplas possibilidades, dúvidas, desejos e principalmente em sua atualidade. "A criança é, agora; ela se chama presente." (LESSA, 1999, s/p.).

Precisamos de uma pedagogia e de um currículo que estejam centrados não na diversidade, mas na diferença, como propõe Silva (2000), concebida como um processo, uma pedagogia e um currículo que não se limitem a celebrar a identidade e a diferença, mas que busquem problematizá-las. Segundo Louro (2007, p. 122-123), ao reconhecer "[...] o cotidiano e o imediato como políticos, não precisamos ficar indefinidamente à espera da completa transformação social para agir."

Qualquer discriminação é imoral e lutar contra ela, segundo Freire (1996, p.25), é um dever, por mais que se reconheça a força dos condicionamentos a enfrentar. Condicionamentos estes que podem estar atrelados a preconceitos em relação à etnia, à classe, aos gêneros, à sexualidade, e que precisam ser quebrados por meio da luta contra todas as formas de discrimina-

172 ção. "A boniteza de ser gente se acha, entre outras coisas, nessa possibilidade e nesse dever de brigar. Saber que devo respeito à autonomia e à identidade do educando exige de mim uma prática em tudo coerente com este saber."

Como explicita Meyer (2008),

E exatamente porque vivemos, hoje, um tempo de emergência e de visibilização de uma multiplicidade de identidades sociais, definidas e disputadas por diferentes movimentos como os feministas, os movimentos de libertação nacional, os movimentos étnico-raciais, os movimentos gays e lésbicos, os movimentos ecológicos (para ficar nos exemplos mais conhecidos e nomeados), e todos estes grupos se fazem representar, ou desejam se fazer representar no espaço escolar e nos currículos que nele se desenvolvem, é que a escola contemporânea é, também, palco de disputas e de conflitos importantes. (MEYER, 2008, p. 21).

Um dos pontos fundamentais na educação das crianças é problematizar e desconstruir o sexismo, a heteronormatividade e outros tipos de preconceitos, pois estes acabam sendo reforçados dentro do ambiente escolar, 
que, dessa forma, não atinge a sua função de ampliar os conhecimentos dos alunos e alunas, e também dos professores/as. (FELIPE, 2008).

Não podemos considerar "culpados" os educadores/as que se acomodam com uma forma de trabalho sexista, pois talvez essa "acomodação" possa advir da falta de preparo e de conhecimento de métodos disponíveis para lidar com tais questões tão pertinentes ao trabalho escolar ou o medo da família e instituições e as consequências que possam surgir da sua intervenção. Entretanto, o medo e a falta de preparo não justificam a não intervenção, pois educador e educadora têm uma responsabilidade perante a sociedade.

É no entrelaçamento entre ação política e ética, em que a prática dá o tom, que os/as educadores/as começam a revelar a existência de uma revolução silenciosa. Para Abib (201 1, p. 17-18), revolução silenciosa é aquela "[...] que acontece enquanto estamos distraídos pensando em outra coisa. Não percebemos que ela acontece, mesmo que, como é o caso com a maioria das revoluções, faço muito barulho." $E$, mais adiante afirma: "[...] $E$, em uma espécie de cegueira, não percebemos que há uma revolução cultural em curso: a revolução dos direitos humanos." (ABIB, 201 1, p. 17-18).

E, nesse ponto, citamos Boaventura de Sousa Santos (2002), apresentando a sua epistemologia da cegueira e a epistemologia da visão. Propõe o autor que a cegueira dos outros, em especial dos outros do passado, é tão recorrente quanto fácil de identificar. Porém, se é assim, provavelmente o que dissermos hoje sobre a cegueira dos outros será visto no futuro como sinal da nossa cegueira. Esse dilema pode ser formulado desta forma, segundo o autor: "Se somos cegos, porque vemos tão facilmente a cegueira dos outros e por que razão é tão difícil aceitar a nossa própria cegueira? Porque julgamos ver plenamente o que só vemos muito parcialmente? E se assim é, de que vale sequer ver?" (SANTOS, 2002, p. 226).

A epistemologia da visão propõe uma forma de saber cujo momento é a solidariedade.

Enquanto pela forma hegemónica de conhecimento, conhecemos criando ordem, a epistemologia da visão levanta a questão sobre se é possível conhecer criando solidariedade. A solidariedade como forma de conhecimento é o reconhecimento do outro como igual, sempre que a diferença the acarrete inferioridade, e como diferente, sempre que a igualdade the ponha em risco a identidade. (SANTOS, 2002, p. 246). 
Assim, das duas epistemologias, é possível conceber "[...] a emergência de um conhecimento prudente para uma vida decente" (SANTOS, 2002, p. 253), um conhecimento que reconhece as experiências e as expectativas, as ações e as consequências, num saber solidário. "A aspiração última é demasiado humana, uma aspiração que designo por normalidade avançada: a aspiração de viver em tempos normais, ou seja, tempos cuja normalidade não derive, como acontece agora, da naturalização da anormalidade." (SANTOS, 2002, p. 2531.

As palavras de Boaventura são extremamente apropriadas para as nossas discussões, ensejando o que procuramos apresentar. Estamos à procura de "um conhecimento prudente para uma vida decente" (SANTOS, 2002), um conhecimento que, por meio da solidariedade, não reproduza mais os modelos discriminatórios que produzem exclusões.

Como educadores e educadoras éticos/as, é absolutamente essencial ao trabalho educativo ter claros os princípios, que, como citam Müller e Rodrigues (2002) e Mager, Müller, Silvestre e Morelli (201 1), se fundam especialmente na radicalidade da inclusão, na participação ativa, no respeito à pessoa e à cultura, no diálogo e na responsabilidade. Se nos pautarmos

174 nesses princípios em nossa prática educativa, já estaremos dando um grande passo rumo a mudanças de paradigmas.

A escola tanto pode dar continuidade a preconceitos e estereótipos como favorecer a criação de espaços em que se discutam as diferenças e o respeito às diversidades. Essa instituição tem muito a fazer pelas crianças. A infância urge. Pequeno é o tempo de brincar, de imaginar, de estudar, de conquistar dignidade. É preciso criar situações de crise, dando condições para que se produzam novas formas de entendimento e novas práticas de superação capazes de alargar novos horizontes.

\section{Notas}

1 Esta pesquisa compõe parte de um estudo mais aprofundando, proposto de intervenções e práticas pedagógicas com crianças e docentes, apresentadas na dissertação de mestrado intitulada: Crianças e professoras com a palavra: gênero e sexualidade nas culturas infantis (2013)..

2 Trilhas da Diversidade foi um jogo de tabuleiro construído pelas autoras, com o fim específico de intervenção e formação, discutindo as temáticas de gênero e sexualidade em diferentes contextos, oferecendo a dinâmica de cartas com perguntas e respostas. 
3 As professoras foram identificadas com os seguintes nomes, visando manter o sigilo da sua participação na pesquisa: Begônia, Azaléia, rosa, Margarida, Gardênia, Hortênsia, Tulipa, Petúnia, Violeta, Gloriosa, Iris, Magnólia e Palma. Além disso, suas falas foram apresentadas em itálico.

4 Optamos pela utilização do termo educação sexual sem entrar no embate semântico da palavra. Orientamo-nos pelas discussões realizados por Furlani, (2005), citando o autor Richard Johnson (1996) com o termo educação da sexualidade. $\bigcirc$ autor abandona o uso da expressão educação sexual por acreditar que a palavra estaria impregnada do enfoque biológico, médico e "conservador". Contudo, a autora afirma que, ao invés de abandonar o termo, teria o mesmo efeito resignificar o adjetivo "sexual" a partir do substantivo "sexualidade". Para mais informações, ver: Jimena Furlani - O bicho vai pegar! - um olhar pós-estruturalista à Educação Sexual a partir de livros paradidáticos infantis. 2005. 272 f. Tese (Doutorado em Educação) - Programa de Pós-Graduação em Educação, Faculdade de Educação, Universidade Federal do Rio Grande do Sul, 2005.

5 Algumas teóricas feministas têm utilizado o termo genderizar para representar características separadas/definidas para cada gênero (gender em inglês).

\section{Referências}

ABIB, José Antônio Damásio. Prefácio. In: MAGER, Miryam; MULLER, Verônica Regina; SILVESTRE, Eliana; MORELLI, Ailton José. Práticas com crianças, adolescentes e jovens: pensamentos decantados. Maringá: Eduem, 2011.

AZALÉIA. Relato. Sarandi/Paraná, 14 e 21 mar. 2012.

BEGÔNIA. Relato. Sarandi/Paraná, 14 e 21 mar. 2012.

BRAGA, Eliane Rose Maio. Gênero, sexualidade e educação: questões pertinentes à Pedagogia. In: CARVALHO, Elma Julia Gonçalves de; FAUSTINO, Rosângela Célia (Org.). Educação e diversidade cultural. 2 ed. Maringá: Eduem, 2009. (v. 1).

CUNHA, Lúcia Karla da Rocha; SANTOS, Thatiana Peixoto dos; SILVA, Flávia Maria Soares da. Gênero e sexualidade na formação de professores. In: SEMINÁRIO NACIONAL GÊNERO E PRÁtICAS CULTURAIS: CULTURAS, LEITURAS E REPRESENTAÇÕES, 2., 2009, João Pessoa. Anais... João Pessoa, UFPB, 2009. Disponível em: <http://itaporanga.net/genero/gtb/14.pdf>. Acesso em: 06 jun. 2011.

FELIPE, Jane. Educação para a sexualidade: uma proposta de formação docente. Salto para o futuro/TV escola: Educação para a igualdade de gênero, n. 26, p. 1-54, nov. 2008.

FOUCAULT, Michel. Vigiar e punir: o nascimento da prisão. 22. ed. Petrópolis: Vozes, 2000. 
FREIRE, Paulo. Pedagogia da autonomia: saberes necessários à prática educativa. São Paulo: Paz e Terra, 1996.

FURLANI, Jimena. O Bicho vai pegar! - um olhar pós-estruturalista à Educação Sexual a partir de livros paradidáticos infantis. 2005. 272 f. Tese (Doutorado em Educação) - Programa de Pós-Graduação em Educação, Universidade Federal do Rio Grande do Sul, Porto Alegre, 2005.

GLORIOSA. Relato. Sarandi/Paraná, 14 e 21 mar. 2012.

HORTÊNSIA. Relato. Sarandi/Paraná, 14 e 21 mar. 2012.

LEÃO, Andreza Marques de Castro; RIBEIRO, Paulo Rennes Marçal. A presença/ausência das temáticas sexualidade e gênero em um curso de pedagogia. In: SEMINÁRIO INTERNACIONAL ENLAÇANDO SEXUALIDADES: EDUCAÇÃO, SAÚDE, MOVIMENTOS SOCIAIS, DIREITOS SEXUAIS E DIREITOS REPRODUTIVOS, 1., 2009, Salvador. Anais... Salvador: Universidade do Estado da Bahia, 2009. Disponível em: <http://www. ses.uneb.br/anais/A\%2OPRESEN\%C3\%87A\%20AUS\%C3\%8ANCIA\%2ODAS\%20 TEM\%C3\%8 1TICAS\%20SEXUALIDADE\%20E\%20G\%C3\%8ANERO\%20EM\%2OUM.pdf>. Acesso em: 06 jun. 2011.

176 LESSA, Patrícia. Sete notas sobre o imaginário infantil. Cadernos de apoio ao ensino, Maringá, n. 7, p. 73-90, dez. 1999.

LIONÇO, Tatiana; DINIZ; Débora (Org.). Homofobia e educação: um desafio ao silêncio. Brasília: LetrasLivres, EdUnB, 2009.

LOURO, Guacira Lopes. Gênero, sexualidade e educação: uma perspectiva pós-estruturalista. Petrópolis: Vozes, 2007.

Gênero e sexualidade: pedagogias conteporâneas. Pro-Posições, Campinas, v.

19, n. 2, p.17-23, ago. 2008.

MAGER, Miryam; MUlLER, Verônica Regina; SILVESTRE, Eliana; MORELLI, Ailton José. Práticas com crianças, adolescentes e jovens: pensamentos decantados. Maringá: Eduem, 2011.

MARGARIDA. Relato. Sarandi, 14 e 21 mar. 2012.

MEYER, Dagmar Estermann. Gênero e sexualidade na educação escolar. Salto para o futura/TV escola: Educação para a igualdade de gênero. TV, n. 26, p. 1-54, 2008. 
MÜLLER, Verônica Regina; RODRIGUES, Patrícia Cruzelino. Reflexões de quem navega na educação social: uma viagem com crianças e adolescentes. Maringá: Clichetec, 2002.

NETO, Otávio Cruz; MOREIRA, Marcelo Rasga; SUCENA, Luiz Fernando Mazzei. Grupos focais e pesquisa social qualitativa: o debate orientado como técnica de investigação. In: ENCONTRO DA ASSOCIAÇÃO BRASILEIRA DE ESTUDOS POPULACIONAIS, 13., 2002, Ouro Preto. Anais... Ouro Preto: UFMG, 2002. Disponível em: <http://www.abep.nepo. unicamp.br/docs/anais/pdf/2002/ Com_JUV_PO27_Neto_texto.pdf>. Acesso em: 02 jun. 2012.

RIBEIRO, Paula Regina Costa. A sexualidade como um dispositivo histórico de poder. In: SOARES, Guiomar Freitas; SILVA, Méri Rosane Santos da; RIBEIRO, Paula Regina Costa (Org.). Corpo, gênero e sexualidade: problematizando práticas educativas e culturais. Rio Grande: Ed. Da FURG, 2006.

ROSA. Relato. Sarandi/Paraná, 14 e 21 mar. 2012.

SANTOS, Boaventura de Souza. A crítica da razão indolente: contra o desperdício da experiência. 4. ed. São Paulo: Cortez, 2002.

SOARES, Guiomar Freitas. Da invisibilidade à cidadania: um estudo sobre as identidades de gênero. SOARES, Guiomar Freitas; SILVA, Méri Rosane Santos da; RIBEIRO, Paula Regina Costa (Org.). Corpo, gênero e sexualidade: problematizando práticas educativas e culturais. Rio Grande: Ed. Da FURG, 2006.

Profa. Ms. Cássia Cristina Furlan

Universidade Estadual de Maringá Prefeitura Municipal de Londrina Grupo de Estudos Infância, Adolescência e Juventude Grupo de Estudo das pedagogias do corpo e da sexualidade | GEPECOS E-mail | cassia.furlan@hotmail.com 
Profa. Dra. Verônica Regina Müller Universidade Estadual de Maringá Programa de Pós-Graduação em Educação Líder do Grupo de Estudos Infância, Adolescência e Juventude Coordenadora do Programa Multidisciplinar de Estudos, Pesquisa e Defesa da Criança e do Adolescente | PCA E-mail | veremuller@gmail.com

Recebido 31 jul. 2013

Aceito 10 nov. 2013 